\title{
Molecular Basis of Lactase Levels in Adult Humans
}

\author{
Johanna C. Escher, ${ }^{*}$ Nellieke D. de Koning, ${ }^{\star}$ Carla G. J. van Engen, ${ }^{\star}$ Sanjeev Arora, ${ }^{*}$ \\ Hans A. Büller," Robert K. Montgomery," and Richard J. Grand* \\ ${ }^{*}$ Division of Pediatric Gastroenterology and Nutrition, Department of Pediatrics, Boston Floating Hospital, and ${ }^{\ddagger}$ Division of \\ Gastroenterology, Department of Medicine, New England Medical Center Hospitals and Tufts University School of Medicine, Boston, \\ Massachusetts 02111; and ${ }^{\S}$ Division of Pediatric Gastroenterology, Academic Medical Center, University of Amsterdam, The Netherlands
}

\begin{abstract}
The molecular basis of adult human "lactase deficiency" has long been a subject of controversy. To address this issue, small intestinal biopsies from oriental, black, and white patients were analyzed. Adjacent samples were assayed for lactase and sucrase specific activities and the sucrase/lactase ratio (high ratio signifies lactase deficiency), and the results were compared to lactase steady-state mRNA levels detected in Northern blots probed with a human lactase cDNA. All oriental patients had high ratios and no detectable lactase mRNA. Four black patients had a similar pattern; two with low ratios had detectable mRNA. The group of white patients displayed a range of findings, from high ratio/no mRNA to low ratio/considerable mRNA. Elevated levels of lactase mRNA always correlated with the presence of elevated levels of lactase enzyme activity, suggesting that the difference in levels of adult human intestinal lactase activity among racial groups may be regulated at the level of gene transcription. (J. Clin. Invest. 1992. 89:480483.) Key words: disaccharidases • lactase deficiency • milk intolerance $\bullet$ transcription
\end{abstract}

\section{Introduction}

Suckling or milk drinking by newborns is one of the defining characteristics of mammals. Milk drinking by adults is considered normal among populations of Northern European extraction and only a few other racial groups. This is in dramatic contrast to the practice of most human groups and all other adult placental mammals, in whom significant milk ingestion results in mild to severe gastrointestinal symptoms, caused by the inability to digest lactose (1).

Lactose, the dominant carbohydrate in virtually all mammalian milk, is hydrolyzed in the small intestine by the microvillus membrane enzyme lactase-phlorizin hydrolase (EC 3.2.1.23; 3.2.1.62), subsequently referred to as lactase. The capacity for milk digestion in adult humans results from the persistence of high juvenile levels of lactase activity into adulthood in some populations (1). Although population genetic analysis indicates that elevated lactase activity is inherited as a single autosomal dominant gene (2), little is known of its mechanism of regulation. We present data that suggest basic regulation at the level of gene transcription; adults with elevated lactase enzyme activity have elevated lactase mRNA levels, while those with low enzyme levels have low lactase message levels.

Address reprint requests to Dr. Grand, Box 213, New England Medical Center Hospitals, 750 Washington Street, Boston, MA 02111. 1991.

Received for publication 21 May 1991 and in revised form 7 October

J. Clin. Invest.

(C) The American Society for Clinical Investigation, Inc.

0021-9738/92/02/0480/04 \$2.00

Volume 89, February 1992, 480-483

\section{Methods}

Patients. Adult patients (aged 19-85 yr) undergoing diagnostic upper gastrointestinal endoscopy in our hospital were asked to participate in the study. Signed, informed consent was obtained from each patient who agreed to participate. Indications for endoscopy included chronic abdominal pain without diarrhea, dysphagia, "dyspepsia," achalasia, and peptic ulcer disease. Patients were divided into three groups according to their genetic background: orientals, blacks, and whites. Patients with bleeding disorders, or severe heart, liver, or lung disease were excluded from the study. From each patient, three mucosal pinchbiopsy specimens ( $\sim 2 \mathrm{~mm}$ in diameter) were taken from the distal end of the third portion of the duodenum during endoscopy. Since intestinal disease was not at issue, biopsies of the intestine were not routinely sent for histologic examination. This protocol was approved by the Human Investigation Review Committee, New England Medical Center Hospitals.

Isolation of human lactase cDNA. To examine human lactase mRNA levels, we prepared a specific human lactase cDNA probe by screening an adult human small intestinal cDNA expression library produced in the vector $\lambda$ gt 11 (generously donated by Dr. Lawrence Chan, Baylor College of Medicine, Houston, TX) with the cDNA for rat lactase previously described by our group (3). Three positive cDNA clones were isolated and plaque purified; probes were successfully generated from these clones using synthetic amplification primers and the polymerase chain reaction (PCR) ${ }^{1}$ as follows: Two amplification primers were designed using two 24-base sequencing primers, 1218 and 1222 (New England Biolabs, Beverly, MA) that flank the EcoR 1 insertion site of the vectors as a basis (4). To the $5^{\prime}$ end of each of these primers was added the base sequences coding for the restriction sites recognized by SAL1 and NOT1, respectively. These were extended with a noncoding terminal base triplet. The identity and sequences of the synthetic oligonucleotides used are as follows:

SAL1 (1218)

\section{= 5' ACGGTCGACGGTGGCGACGACTCCTGGAGCCCG 3'}

\section{NOT1 (1222)}

\section{= 5' GACGCGGCCGCTTGACACCAGACCAACTGGTAATG 3'}

The primers showed no homology to the published sequence of human lactase (5).

The PCR was performed as follows by using Taq polymerase (Amplitaq, Perkin-Elmer Cetus, Norwalk, CT). Crude phage preparations of the isolated clones were subjected to 30 cycles of amplification: DNA was denatured at $94^{\circ} \mathrm{C}$ for $45 \mathrm{~s}$, primers annealed at $45^{\circ} \mathrm{C}$ (first $5 \mathrm{cy}$ cles) or at $55^{\circ} \mathrm{C}$ (subsequent 25 cycles) for $45 \mathrm{~s}$, and primers were extended at $72^{\circ} \mathrm{C}$ for $1 \mathrm{~min}$ and $20 \mathrm{~s}$. Thermal cycling was performed in a programmable heat block (Perkin-Elmer Cetus). After the last cycle, all samples were heated for an additional $7 \mathrm{~min}$ at $72^{\circ} \mathrm{C}$ to ensure that extension was complete. Th amplified sequences demonstrated lengths varying from 0.3 to $0.45 \mathrm{~kb}$.

For direct sequencing of the PCR products, the same primers were 5 ' end-labeled. The three clones were partially dideoxy-sequenced, with modifications to permit the substitution of T7 DNA polymerase (Sequenase version 2.0, U.S. Biochemical Corp., Cleveland, $\mathrm{OH}$ ) for the

1. Abbreviation used in this paper: $\mathrm{PCR}$, polymerase chain reaction. 
Klenow fragment of DNA Polymerase I $(6,7)$. Partial sequence analysis of the PCR product, human lactase phlorizin hydrolase cDNA 1 (450 bp), chosen for use as the probe in this study, demonstrated that a single stretch of 109 nucleotides showed $100 \%$ homology to nucleotides 5670-5779 of the published sequence of a human lactase-phlorizin hydrolase cDNA (5). The sequence of the other two PCR products was identical to segments of the untranslated region at the $3^{\prime}$ end of the published sequence. These data established the authenticity of the three clones isolated. The studies described below were carried out with human lactase phlorizin hydrolase cDNA 1 . Authenticity of the probe was further corroborated by its hybridization to a single mRNA band of $\sim 6.8 \mathrm{~kb}$ on Northern blots of total human intestinal RNA, similar to the results with a full-length human lactase cDNA described by Mantei et al. (5).

Quantification of $m R N A$. Immediately after removal, two biopsy specimens from each patient were homogenized in ice-cold $4.0 \mathrm{M}$ guanidinium isothiocyanate containing $3.0 \mathrm{M}$ sodium acetate and $\beta$ mercaptoethanol (GIT buffer) using a glass homogenizer; total RNA was isolated and prepared for Northern blot analysis. Total RNA $(4 \mu \mathrm{g})$ prepared as previously described (3) was loaded in each lane of a denaturing formaldehyde/agarose gel. After electrophoresis, RNA was capillary blotted and hybridized to labeled human lactase phlorizin hydrolase cDNA-1. The probe was labeled by the random primer hexamer method with $\left[\alpha^{-3} \mathrm{P}\right] \mathrm{dCTP}$ (DuPont New England Nuclear, Boston, MA) using DNA Polymerase I large fragment (New England Biolabs). Random hexanucleotides and dNTPs were purchased from Pharmacia, Inc., Piscataway, NJ. Unbound $\left[\alpha-{ }^{32} P\right] d C T P$ was removed by the Sephadex G-50 spun-column procedure (3). For Northern blot analysis, hybridization was performed with the labeled lactase probe (1-3 $\times 10^{6} \mathrm{cpm} / \mathrm{ml}$ hybridization solution) under relatively stringent conditions $\left(24 \mathrm{~h}\right.$ at $42^{\circ} \mathrm{C}$ in a solution containing $50 \%$ formamide, $5 \times$ SSC [SSC $1 \times$ is $0.15 \mathrm{M} \mathrm{Nal} / 0.015 \mathrm{M}$ sodium citrate, $\mathrm{pH} 7.0$ ], $50 \mathrm{mM} \mathrm{Na}-$ phosphate [pH 6.5], $5 \times$ Denhardt's, $250 \mu \mathrm{g} / \mathrm{ml}$ sonicated salmon sperm DNA, and $0.1 \%$ SDS). Blots were washed four times in $2 \times$ SSC $+0.1 \%$ SDS at room temperature, and four times in $2 \times \mathrm{SSC}+0.1 \%$ $\mathrm{SDS}$ at $50^{\circ} \mathrm{C}$, for $15 \mathrm{~min}$ each. For autoradiography, the blot was exposed to XAR-5 film (Eastman Kodak Co., Rochester, NY) for $24 \mathrm{~h}$ at $-70^{\circ} \mathrm{C}$ using one intensifying screen. As an independent measure of total RNA loading, blots were hybridized to an end-labeled, synthetic oligonucleotide probe for human $\beta$-actin (Oncogene Science, Inc., Manhasset, NY), according to the manufacturer's instructions.

For slot blot analysis, $4 \mu \mathrm{g}$ of total RNA were prepared (8) and bound to Genescreen, using a slot-blot apparatus (Bio-Rad Laboratories, Richmond, CA). The RNA was linked to the membrane, prehybridized, and hybridized with h-LPH-cDNA-1 as described above. Exposure was 1 wk at $-70^{\circ} \mathrm{C}$.

Enzyme and protein assays; calculation of activity ratios. One of the intestinal biopsy specimens from each patient was homogenized and assayed for lactase and sucrase activities, and protein content (9). The measured enzyme activity was used as the criterion of low and elevated lactase, because the available data indicate that lactase enzyme activity is a direct function of the amount of lactase protein present (9). Since sucrase activity does not decrease in lactase-deficient patients (10-12), the ratio of sucrase activity to lactase activity provides a useful index of "lactase deficiency." Two independent studies encompassing more than 100 patients apiece, in which both lactose tolerance and enzyme activities were analyzed $(10,11)$, demonstrated that the ratio of sucrase to lactase activity correlated well with lactose tolerance or intolerance. The first study (10) found that 94 tolerant patients had ratios from 0.5 to 4.3 (mean $=2.00$ ), while the intolerant subjects had ratios from 10.4 to infinity. A second (11), which examined 100 deficient and 150 normal lactase patients, concluded that a ratio of 4 or less indicated normal lactase levels. The sucrase activities measured in the biopsies used in this study fell within the normal range (10). As described below, we have found that those subjects with ratios of 2 or less showed easily detectable lactase mRNA, consistent with these earlier studies, and have used ratios greater than or less than 2 (the mean value determined by Newcomer and McGill (10) in their study) as our criterion.

\section{Results}

The sucrase/lactase ratios and presence or absence of lactase mRNA for the 31 patients examined in this study are summarized in Table I. All of the oriental patients had low specific activities (average value: $5.1 \mathrm{U} / \mathrm{g}$ ). The six blacks and six of the white subjects had slightly higher lactase enzyme specific activities ( 9.2 and 7.0, respectively). The seven whites with readily detectable mRNA had distinctly higher values (average 41.3 $\mathrm{U} / \mathrm{g}$ ). We did not observe any cases in which patients who displayed readily apparent lactase mRNA displayed very low levels of enzyme activity, nor did we observe high levels of enzyme activity in any patient who did not also have easily detectable lactase mRNA. Thus, the presence of high levels of lactase mRNA was correlated exactly with the presence of increased levels of lactase enzyme activity.

Hybridization data from a representative sample of patients, four orientals, three blacks, and seven whites, are shown in Fig. 1, left. No lactase mRNA was detected in any of the oriental patients (lanes 1-5), all of whom displayed low lactase activity and high sucrase/lactase ratios. Two black patients did not show easily detectable lactase mRNA (lanes 6 and 7). The third black patient (lane 8 ), who had a ratio below 2 , showed considerable lactase mRNA. The white patients with elevated lactase activity (and low sucrase/lactase ratios) had easily detectable lactase mRNA (lanes $9,10,12,14$, and 15), while those with low lactase and high ratios had little or no detectable lactase mRNA (lanes 11 and 13). Hybridization of the same blot with the probe for $\beta$-actin (Fig. 1) demonstrated that the loading of the lanes with total RNA did not explain the pattern of lactase mRNA. In fact, the oriental patients with no detectable lactase mRNA showed some of the highest expression of actin mRNA. Lack of lactase mRNA signal was therefore not due to errors in loading the gel. Increasing the exposure of the blots gave faint signals in several of the low lactase lanes (data not shown), which is not unexpected, since all of the individuals examined had some detectable lactase activity, indicating the presence of small amounts of lactase protein.

Fig. 1, right displays the result of plotting lactase specific activity vs. the ratio of lactase mRNA to actin mRNA (from Fig. 1, left). These data suggest a correlation between the amount of lactase mRNA and lactase specific activity, as well as confirming the distribution of lactase mRNA levels among the three groups.

Table I. Distribution of Sucrase/Lactase Activity Ratios and Presence of Lactase mRNA (+) in Human Intestinal Biopsy Samples in Three Racial Groups

\begin{tabular}{|c|c|c|c|}
\hline \multirow[b]{2}{*}{ Data } & \multicolumn{3}{|c|}{ Number of subjects } \\
\hline & Orientals & Blacks & Whites \\
\hline Ratio $>2$ & 12 & 4 & 6 \\
\hline Ratio $<2$ & $\underline{0}$ & $\underline{2}$ & 7 \\
\hline Total & $\overline{12}$ & $\overline{6}$ & $\overline{13}$ \\
\hline Lactase mRNA $(-)$ and ratio $>2$ & 12 & 4 & 6 \\
\hline Lactase mRNA $(+)$ and ratio $<2$ & 0 & 2 & 7 \\
\hline
\end{tabular}

A ratio $<2$ signifies elevated or "normal" lactase enzyme activity. The patients with ratios $<2$ and positive for lactase mRNA are the same individuals. 


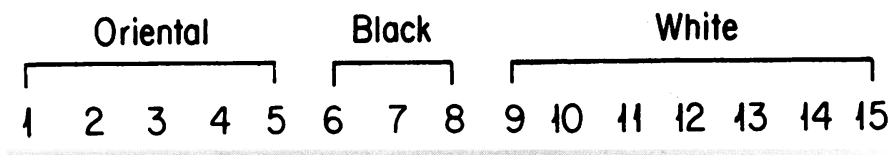

Lactose mRNA

\section{Actin mRNA}

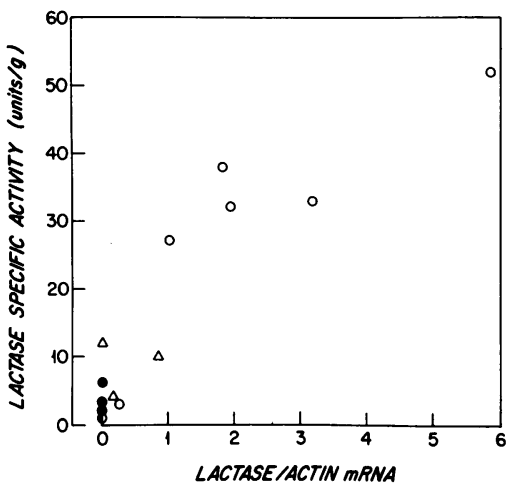

Figure 1. Representative Northern blot of lactase mRNA from five oriental, three black, and seven white patients and quantitative analysis of densitometric data. Left: $4 \mu \mathrm{g}$ of total human intestinal RNA were prepared and hybridized to the labeled h-LPH-cDNA-1 as described in Methods. The strip at the bottom displays the result of hybridizing the same blot to a human $\beta$-actin probe. Right: Comparison of lactase specific activity to lactase/actin mRNA levels. The amount of lactase and actin mRNA in each sample was determined in arbitrary units by densitometry and a ratio between lactase and actin was calculated. These ratios were plotted against the measured lactase specific activity for each subject. (๑) oriental patients; $(\Delta)$ black patients; $(0)$ white patients.

In order to try to detect faint signals, slot blot analysis was carried out on representative samples of oriental, black, and white patients as shown in Fig. 2. Extended exposure (1 wk) of the samples from patients who showed no lactase mRNA by Northern blot gave only faint signals, confirming that the amount of lactase mRNA in these subjects was considerably lower than in the high lactase patients, consistent with the enzyme analysis.

\section{Discussion}

The distribution of elevated lactase activities in adult humans described in this study is consistent with numerous population analyses $(1,2)$. These have shown that few or no adult orientals have elevated lactase activity; American blacks have a variable prevalence of elevated lactase activity (depending on the population examined); and American whites have the highest percentage of elevated lactase activity. The latter two groups are far from homogeneous in lactase expression. As summarized by Flatz (2), the frequency of elevated lactase activity in European whites varies with country of origin, generally in a north to south gradient, from $100 \%$ in a study of Dutch subjects to $<30 \%$ among Sicilians. Clearly, there is a strong population

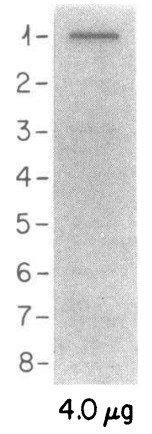

Figure 2. Slot-blot hybridization of human lactase mRNA in intestinal biopsy samples. Sample $l$ is a white subject, positive by Northern blot. Samples 2 and 3 are from white subjects, 5 from a black, and 6,7 , and 8 from oriental subjects all of whom were negative by $4.0 \mu \mathrm{g} \quad$ Northern blot. Slot 4 had no RNA added. genetic component to the prevalence of elevated lactase levels in adult humans.

Lactase activities in adult humans were first assayed in Northern European populations where milk drinking and elevated lactase levels are common $(13,14)$. Decreased lactase activity was associated with intestinal upset, and was described as a "deficiency disease." This approach focused research on the mechanism of the decline as an abnormality, analogous to the well-studied lysosomal storage diseases, and led to efforts to delineate the mechanism of decline. However, it is now clear that elevated lactase activity in adults, not decreased activity, is the unusual or "abnormal" condition.

An examination of the molecular basis of lactase regulation in surgical patients in Naples (15) found high enzyme activity with high mRNA, low enzyme activity with high mRNA, and high enzyme activity with low mRNA in different individuals. Based on this lack of correlation between enzyme and mRNA levels, the authors concluded that lactase enzyme levels showed no obvious correlation with lactase mRNA, and was therefore not regulated transcriptionally. Although the origin of the patients in this study was not identified, it is likely that most, if not all, were of white Italian extraction. As discussed below, it appears likely that there are several different mechanisms leading to low lactase levels in whites. Thus, the study does not address the well-described differences found between racial groups, as we have in the present work. Additionally, a possible explanation for the discrepancy between enzyme and mRNA levels is the difficulty in preserving intact mRNA from intestinal samples, particularly when obtained at surgery. In our study, biopsy specimens were immediately homogenized in guanidinium as soon as they were removed from the endoscope, to minimize degradation.

Two recent studies in which lactase protein synthesis was examined suggest that human intestinal lactase levels are determined by the rate of synthesis of the enzyme. Sterchi et al. (16) recently reported a careful examination of lactase synthesis in 
18 lactose tolerant and 14 intolerant patients. Their data indicate that the lactase intolerant subjects had reduced levels of lactase enzyme, owing to a greatly decreased rate of lactase synthesis compared to the tolerant subjects. The structure of lactase was identical in both groups. They also identified some specific defects in intracellular transport and processing in some of the individuals with reduced lactase activity. Witte et al. (17), identified markedly reduced synthesis in three deficient patients with low lactase enzyme levels, and decreased conversion of precursor to mature lactase in a fourth deficient patient. Together, these studies suggest that $(a)$ the major determinant of lactose "intolerance" is reduced synthesis of lactase enzyme, and $(b)$ within racial groups which commonly display high lactase activity, there are individuals with specific defects in synthesis and processing, such as have been identified for sucrase-isomaltase deficiency (18). Since the level of mRNA present is a critical factor in determining the rate of protein synthesis, these data are consistent with ours. A recent study of biopsy samples from six patients, correlating lactase enzyme activity, protein synthesis, and mRNA levels, presented in abstract form by Lloyd et al. (19), also concluded that the fundamental level of regulation was transcriptional.

Alterations in enzyme processing at weaning have recently been suggested as a mechanism for the decline in rat lactase activity (20). A further possible mechanism is suggested by the recent report by Maiuri et al. (21) of both complete absence and mosaic expression of lactase immunoreactivity in the intestinal epithelium in a group of adult patients with hypolactasia. Recent cDNA sequencing of lactase from deficient and sufficient patients demonstrated no difference in the coding regions between the two, and no differences in the intron-exon boundaries, indicating that both genes are identical, and that both make identical proteins (22).

These data are consistent with the hypothesis that human lactase enzyme activity is a direct result of the level of expression of lactase mRNA, although other mechanisms may modify the final enzyme level. Our data are a measure of steadystate mRNA levels and do not address potential alterations in transcription rate or mRNA stability. However, transcriptional regulation is the predominant mechanism described for organspecific protein synthesis (23), and is likely to be so for lactase. Thus, the overall pattern in the human population appears similar to that described in rats, where enzyme levels and mRNA levels are coordinate in development $(3,24)$. Elevated lactase levels in specific population groups, which have been correlated with the presence of an autosomal dominant gene, appear due to an increased abundance of lactase mRNA, likely a result of elevated transcription. The molecular control of this elevated expression remains to be elucidated.

\section{Acknowledgments}

We thank Dr. L. Chan, Departments of Cell Biology and Medicine, Baylor College of Medicine, Houston, TX for his human small intestinal cDNA library. We are grateful to the members of the endoscopy suite staff of the New England Medical Center Hospitals for their generous assistance in these studies. We also want to express gratitude to our colleagues, Drs. Andrew Leiter and Alan Kopin, for help and encouragement during the course of these studies.

This work was supported in part by the Netherlands Digestive Disease Foundation, Breukelen (Dr. Escher); the Saal van Zwanenberg Foundation (Dr. Escher); Glaxo, Nieuwegein (Dr. de Koning); Nutricia, Zoetermeer, The Netherlands (Dr. Büller); National Institutes of Health Research Grant DK-32658 (Dr. Grand); a grant from the Whi- taker Health Sciences Fund (Dr. Montgomery); and grant P30 DK 34928 to the Center for Gastroenterology Research on Absorptive and Secretory Processes, New England Medical Center Hospitals.

\section{References}

1. Scrimshaw, N. S., and E. B. Murray. 1988. The acceptability of milk and milk products in populations with a high prevalence of lactose intolerance. $\mathrm{Am}$. J. Clin. Nutr. 48:1083-1159.

2. Flatz, G. 1987. Genetics of lactose digestion in humans. In Advances in Human Genetics. H. Harris and K. Hirschhorn, editors. Plenum Publishing Corp., New York. 1-77.

3. Büller, H. A., M. J. C. Kothe, D. A. Goldman, S. A. Grubman, W. V. Sasak P. T. Matsudaira, R. K. Montgomery, and R. J. Grand. 1990. Coordinate expression of lactase-phlorizin hydrolase mRNA and enzyme levels in rat intestine during development. J. Biol. Chem. 265:6978-6983.

4. Saiki, R. K., D. H. Gelfand, S. Stoffel, S. J. Sharf, R. Higuchi, G. T. Horn, K. B. Mullis, and H. A. Erlich. 1988. Primer-directed enzymatic amplification of DNA with a thermostable DNA polymerase. Science (Wash. DC). 239:487-491.

5. Mantei, N., M. Villa, T. Enzler, H. Wacker, W. Boll, P. James, W. Hunziker, and G. Semenza. 1988. Complete primary structure of human and rabbit lactase-phlorizin hydrolase: implications for biosynthesis, membrane anchoring and evolution of the enzyme. EMBO (Eur. Mol. Biol. Organ.) J. 7:2705-2713.

6. Sanger, F., S. Nicklen, and R. Coulson. 1977. DNA sequencing with chain terminating inhibitors. Proc. Natl. Acad. Sci. USA. 74:5463-5467.

7. Wrischnik, L. A., R. G. Higuchi, M. Stoneking, H. A. Erlich, N. Aracheim, and A. C. Wilson. 1987. Length mutations in human mitochondrial DNA: direct sequencing of enzymatically amplified DNA. Nucleic Acids Res. 15:529-535.

8. Sambrook, J., E. F. Fritsch, and T. Maniatis. 1989. Molecular Cloning: A Laboratory Manual. 2nd ed. Cold Spring Harbor Laboratory Press, Cold Spring Harbor, NY. 7.54-7.55

9. Büller, H. A., A. G. van Wassenaer, S. Raghavan, R. K. Montgomery, M. A. Sybicki, and R. J. Grand. 1989. New insights into the lactase and glycosylceramidase activities of rat microvillus membrane (MVM) lactase-phlorizin hydrolase. Am. J. Physiol. 257:G616-G623.

10. Newcomer, A. D., and D. B. McGill. 1967. Disaccharidase activity in the small intestine: prevalence of lactase deficiency in 100 healthy subjects. Gastroenterology. 53:881-889.

11. Welsh, J. D. 1970. Isolated lactase deficiency in humans: report on 100 patients. Gastroenterology. 49:257-277.

12. Welsh, J. D., J. R. Poley, M. Bhatia, and D. E. Stevenson. 1978. Intestinal disaccharidase activities in relation to age, race, and mucosal damage. Gastroen terology. 75:847-855.

13. Dahlqvist, A., J. B. Hammond, R. K. Crane, J. V. Dunphy, and A. Littman. 1963. Intestinal lactase deficiency and lactose intolerance in adults. Gastroenterology. 45:488-491.

14. Kretchmer, N. 1971. Lactose and lactase-a historical perspective. Gastroenterology. 61:805-813.

15. Sebastio, G., M. Villa, R. Sartorio, V. Guzzetta, V. Poggi, S. Auricchio, W. Boll, N. Mantei, and G. Semenza. 1989. Control of lactase in human adult-type hypolactasia and in weaning rabbits and rats. Am. J. Hum. Genet. 45:489-497.

16. Sterchi, E. E., P. R. Mills, J. A. M. Fransen, H. Hauri, M. J. Lentze, H. Y. Naim, L. Ginsel, and J. Bond. 1990. Biogenesis of intestinal lactase-phlorizin hydrolase in adults with lactose intolerance: evidence for reduced biosynthesis and slowed-down maturation in enterocytes. J. Clin. Invest. 86:1329-1337.

17. Witte, J., M. Lloyd, V. Lorenzsonn, H. Korsmo, and W. Olsen. 1990. The biosynthetic basis of adult lactase deficiency. J. Clin. Invest. 86:1338-1342.

18. Naim, H. Y., J. Roth, E. E. Sterchi, M. Lentze, P. Milla, J. Schmitz, and H. Hauri. 1988. Sucrase-isomaltase deficiency in humans: different mutations disrupt intracellular transport, processing, and function of an intestinal brush border enzyme. J. Clin. Invest. 82:667-679.

19. Lloyd, M., G. Mevissen, M. Fischer, W. Olsen, H. Pitot, N. Mantei, and G. Semenza. 1991. Regulation of intestinal lactase in adult hypolactasia. Gastroenterology. 100:A226. (Abstr.)

20. Castillo, R. O., A. M. Reisenauer, L. K. Kwong, K. K. Tsuboi, R. Quan, and G. M. Gray. 1990. Intestinal lactase in the neonatal rat. Maturational changes in intracellular processing and brush-border degradation. J. Biol. Chem. 265:15889-15893.

21. Maiuri, L., V. Raia, J. Potter, D. Swallow, M. W. Ho, R. Fiocca, G. Finzi, M. Cornaggia, C. Capella, A. Quaroni, et al. 1991. Mosaic pattern of lactase expression by villous enterocytes in human adult-type hypolactasia. Gastroenterology. 100:359-369.

22. Boll, W., P. Wagner, and N. Mantei. 1991. Structure of chromosomal gene and cDNAs coding for lactase-phlorizin hydrolase in humans with adult type hypolactasia or persistence of lactase. Am. J. Hum. Genet. 48:889-902.

23. Johnson, P. F., and S. L. McKnight. 1989. Eukaryotic transcriptional regulatory proteins. Annu. Rev. Biochem. 58:799-839.

24. Jonas, M. M., R. K. Montgomery, and R. J. Grand. 1985. Intestinal lactase synthesis during postnatal development in rat. Pediatr. Res. 19:956-962. 